This item is the archived peer-reviewed author-version of:

Cyclopeptide alkaloids from Hymenocardia acida

\title{
Reference:
}

Tuenter Emmy, Exarchou Vasiliki, Balde Aliou, Cos Paul, Maes Louis, Apers Sandra, Pieters Luc.- Cyclopeptide alkaloids from Hymenocardia acida Journal of natural products - ISSN 0163-3864 - 79:7(2016), p. 1746-1751

Full text (Publisher's DOI): http://dx.doi.org/doi:10.1021/ACS.JNATPROD.6B00131

To cite this reference: http://hdl.handle.net/10067/1350300151162165141 


\section{Cyclopeptide Alkaloids from Hymenocardia acida}

Emmy Tuenter, ${ }^{*}{ }^{\dagger}$ Vassiliki Exarchou, ${ }^{\dagger}$ Aliou Baldé ${ }^{\ddagger}$ Paul Cos,${ }^{\S}$ Louis Maes, ${ }^{\S}$ Sandra Apers, ${ }^{\dagger}$ Luc Pieters ${ }^{\dagger}$

${ }^{\dagger}$ Department of Pharmaceutical Sciences, Natural Products \& Food Research and Analysis

(NatuRA), University of Antwerp, Universiteitsplein 1, 2610 Antwerp, Belgium

${ }^{\ddagger}$ Research and Valorization Center on Medicinal Plants, Dubréka, Guinea-Conakry

${ }^{\S}$ Department of Pharmaceutical Sciences, Laboratory of Microbiology, Parasitology and Hygiene (LMPH), University of Antwerp, Universiteitsplein 1, 2610 Antwerp, Belgium 


\begin{abstract}
Four cyclopeptide alkaloids (1-4) were isolated from the root bark of Hymenocardia acida by means of semi-preparative HPLC with DAD and ESIMS detection and conventional separation methods. Compound structure elucidation was performed by spectroscopic data interpretation. Except for the known compound hymenocardine (1), the three other alkaloids were isolated for the first time from a natural source. These included a hymenocardine derivative with a hydroxy group rather than a carbonyl that was named hymenocardinol (2), as well as hymenocardine $N$ oxide (3) and a new cyclopeptide alkaloid containing an unusual histidine moiety that was named hymenocardine-H (4). The isolated cyclopeptide alkaloids were tested for their antiplasmodial activity and cytotoxicity. All four compounds showed moderate antiplasmodial activity with $\mathrm{IC}_{50}$ values ranging from 12.2 to $27.9 \mu \mathrm{M}$, the most active one being hymenocardine $N$-oxide (3), with an $\mathrm{IC}_{50}$ value of $12.2 \pm 6.6 \mu \mathrm{M}$. Compounds $2-4$ were found not to be cytotoxic against MRC-5 cells $\left(\mathrm{IC}_{50}>64.0 \mu \mathrm{M}\right)$, but hymenocardine (1) showed moderate cytotoxicity with an $\mathrm{IC}_{50}$ of $51.1 \pm 17.2 \mu \mathrm{M}$.
\end{abstract}


Hymenocardia acida Tul. is a shrub or small tree of about $6 \mathrm{~m}$ high that grows in the African Savannah. It belongs to the family of the Phyllantaceae, although previously it was classified in the families of the Euphorbiaceae and Hymenocardiaceae. ${ }^{1-3}$ Extracts of this plant have been used in traditional African medicine. For example, the leaves and roots are used to treat malaria, the roots are used against hypertension, and the plant may be employed as an antiseptic and to treat skin diseases. Another application is the use of decoctions of the leaves or roots to relieve pain. ${ }^{4-7}$ Previous phytochemical studies on this plant have shown the presence of alkaloids, anthocyanins, anthraquinones, cardiac glycosides, flavonoids, phenols, saponins, steroids, stilbenoids, tannins and triterpenoids. ${ }^{5-7}$ To date, one cyclopeptide alkaloid, hymenocardine, has been reported. ${ }^{3}$

The antiplasmodial activity and cytotoxicity of extracts from the leaves of $H$. acida has been shown by Vonthron-Senecheau. ${ }^{4}$ Mahmout et al. reported the compounds lupeol, lupeyl docosanoate, and $\beta$-sitosterol to be present in $H$. acida and to have antiplasmodial activity, related to their amphiphilic nature. ${ }^{6}$ Apart from this, little is known about the antiplasmodial constituents of this plant. In view of the traditional use of Hymenocardia acida against malaria, the occurrence of the cyclopeptide alkaloid hymenocardine (1) in the root bark, and the reported antiplasmodial activity of some cyclopeptide alkaloids such as ziziphines N and Q, mauritine $\mathrm{M}$, nummularine $\mathrm{H}$, and hemsine $\mathrm{A},{ }^{8,9}$ it was decided to investigate in more detail the presence of potentially antiplasmodially active cyclopeptide alkaloids in the root bark of $H$. acida. Cyclopeptide alkaloids are polyamidic bases and they form a relatively rare class of natural products. They are macrocyclic compounds, containing a 13-, 14- or 15-membered ring and they can be classified according to the ring size. They consist of a styrylamine unit and three amino acids as common structural elements. ${ }^{10,11}$ 
Root bark of $H$. acida was extracted with $80 \%$ methanol and the crude extract was fractionated by liquid-liquid partitioning, followed by flash chromatography. The isolation of single compounds was performed with semi-preparative HPLC with DAD and ESIMS detection and in this way four cyclopeptide alkaloids were obtained (1-4). Their structures were elucidated by $1 \mathrm{D}\left({ }^{1} \mathrm{H},{ }^{13} \mathrm{C}\right.$, DEPT 135, DEPT 90) and 2D NMR experiments (COSY, HSQC, HMBC) and comparison to literature data, and confirmed by HRESIMS.
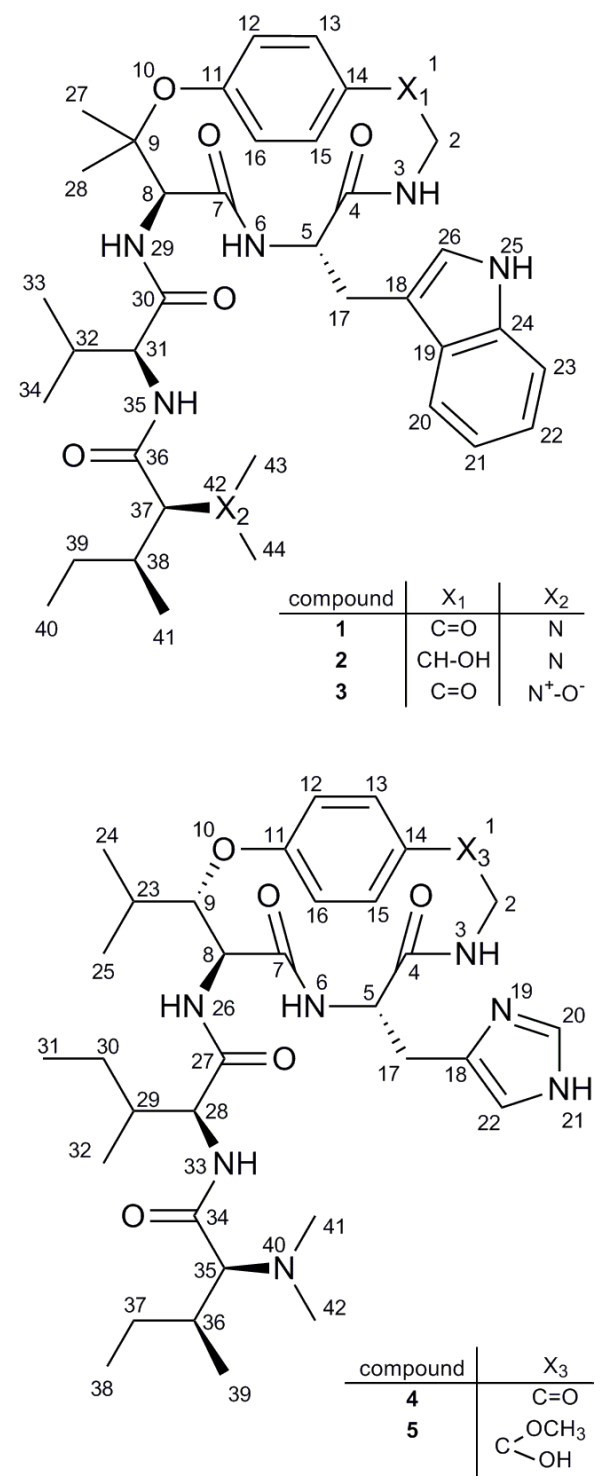
Comparison of the NMR spectra of compound 1 with previously published data showed that this compound is hymenocardine, which was reported to be present in $\mathrm{H}$. acida earlier. ${ }^{3,12}{ }^{1} \mathrm{H}$ and ${ }^{13} \mathrm{C}$ NMR chemical shift assignments for 1 are listed in Tables 1 and 2, respectively.

The NMR spectra of compound $\mathbf{2}$ showed a resemblance to those of compound $\mathbf{1}$, but a carbon signal with $\delta_{\mathrm{C}} 73.4 \mathrm{ppm}$ that correlated with a proton at $\delta_{\mathrm{H}} 5.01 \mathrm{ppm}$ was present, while these signals were absent from the spectra of compound 1. Moreover, the signal at $205.1 \mathrm{ppm}$ in the ${ }^{13} \mathrm{C}$ NMR spectrum of compound $\mathbf{1}$, corresponding to the carbonylgroup at position 1 was absent in the ${ }^{13} \mathrm{C}$ NMR spectrum of compound 2 . This can be explained by the presence of a hydroxy group instead of a carbonyl group at C-1. Thus, compound $\mathbf{2}$ is a reduced analogue of compound 1 and has been named hymenocardinol. Although the reduced form of hymenocardine was obtained before, after chemical modification of $\mathbf{1}$ with sodium borohydride, ${ }^{3}$ this is the first report of compound $\mathbf{2}$ as a natural product.

The structure of compound $\mathbf{3}$ also showed a resemblance to compound $\mathbf{1}$ according to its NMR spectra, but some of the signals corresponding to the terminal amino acid of the side chain showed more downfield chemical shifts. This could be observed for the two N-methyl groups, which resonated at $\delta_{\mathrm{C}} 55.3 \mathrm{ppm} / \delta_{\mathrm{H}} 3.46 \mathrm{ppm}$ and $\delta_{\mathrm{C}} 56.9 \mathrm{ppm} / \delta_{\mathrm{H}} 3.32 \mathrm{ppm}$ respectively, whereas in compound 1 the values of both methyl groups were $\delta_{\mathrm{C}} 42.7 \mathrm{ppm} / \delta_{\mathrm{H}} 2.69 \mathrm{ppm}$. Similarly, the $\mathrm{CH}$ group substituted by the $\mathrm{N}$-dimethyl group was shifted to $\delta_{\mathrm{C}} 82.4 \mathrm{ppm} / \delta_{\mathrm{H}} 3.90$ ppm for compound $\mathbf{3}$, compared to $\delta_{\mathrm{C}} 73.9 \mathrm{ppm} / \delta_{\mathrm{H}} 3.60 \mathrm{ppm}$ for compound $\mathbf{1}$. A similar pattern was reported by Han et al. ${ }^{13}$ for cyclopeptide alkaloids containing an N-oxide group. Thus, compound $\mathbf{3}$ was identified as hymenocardine $\mathrm{N}$-oxide. Although it is not uncommon that cyclopeptide alkaloids are isolated as $N$-oxides, together with tertiary amines, ${ }^{13}$ the possibility 
that the $\mathrm{N}$-oxides are artefacts formed during drying, extraction or isolation cannot completely be excluded.

In contrast with the previous two compounds, compound $\mathbf{4}$ was not closely related structurally to hymenocardine (1), as deduced from the NMR spectra. The structure of this compound was elucidated based on the interpretation of its 2D-NMR spectra (COSY, HSQC, and HMBC). Instead of a $\beta$-hydroxyvaline unit, present as one of the ring-bound amino acids in compounds 13, this compound was found to contain a $\beta$-hydroxyleucine moiety, and in the side chain isoleucine was present instead of valine. Moreover, the 14-membered ring also contained a histidine moiety, whereas a tryptophan moiety was present in compounds 1-3. The presence of histidine was confirmed by comparison with published NMR data for this amino acid. ${ }^{15}$ To the best of our knowledge this is the first report of a cyclopeptide alkaloid containing a histidine moiety. Owing to the presence of this amino acid, compound $\mathbf{4}$ was named hymenocardine- $\mathrm{H}$.

${ }^{1} \mathrm{H}$ and ${ }^{13} \mathrm{C}$ NMR chemical shift assignments for compounds $\mathbf{1}-\mathbf{4}$ are listed in Tables 1 and 2, respectively. For compounds 1-3, ${ }^{13} \mathrm{C}$ NMR spectra were recorded in methanol- $d_{4}$ and the spectra were recorded in DMSO- $d_{6}$ for 4 . When NMR spectra in methanol- $d_{4}$ were recorded for this compound, an artifact (compound 5) was detected, which was identified as the hemi-acetal form of compound 4 , formed after reaction with the solvent (methanol- $\left.d_{4}\right)$. This was deduced from the presence of a signal at $105.5 \mathrm{ppm}$ in the ${ }^{13} \mathrm{C}$ NMR spectrum, while there was no signal for the carbonyl C-atom at C-1, which would have a chemical shift of more than $200 \mathrm{ppm}$.

Amino acids that occur in nature are usually present in the L-configuration. Also in cyclopeptide alkaloids this configuration is found in the vast majority and only rarely the D-configuration has been reported, for example in scutianine-E, isolated from Scutia buxifolia. ${ }^{\text {Morel, }}{ }^{2005}$ The configuration of hymenocardine (1) has been described in 1968 by Pais et al. and indeed the L- 
configuration was found for the tryptophan, the valine and the $\mathrm{N}$-dimethyl-isoleucine present in this cyclopeptide alkaloid. ${ }^{3}$ For the four compounds that are described in this note, no specific experiments were performed to determine the stereochemistry, but conforming to the already reported configuration of hymenocardine and the occurance of the L-form in almost all cyclopeptide alkaloids, the L-configuration was adopted for the amino acid moieties present in compounds 1-4. For hymenocardine-H (4) the stereochemistry of the $\beta$-hydroxy amino acid, $\beta$ hydroxy leucine, was established as L-erythro based on the available NMR data. The coupling constant of the doublet corresponding to $\mathrm{H}-9$ was $8.5 \mathrm{~Hz}$, indicative for an erythro configuration. In addition, the chemical shifts of C-9 and C-8 were $81.8 \mathrm{ppm}$ and $54.9 \mathrm{ppm}$, respectively, both indicative for the L-amino acid form. Furthermore, the $J$ value of ${ }^{1} \mathrm{H}$ NMR signal attributed to the methylgroup in position 25 was $6.7 \mathrm{~Hz}$, indicative for a pseudoaxial / equatorial coupling, typical for L-erythro- $\beta$-hydroxyleucine. ${ }^{11,14}$ 
Table 1. ${ }^{1} \mathrm{H}$ NMR Spectroscopic Data $\left(\delta_{\mathrm{H}}\right.$ in ppm, Multiplicity $(J$ in $\mathrm{Hz})$ ) for Compounds 1$5^{a}$

\begin{tabular}{|c|c|c|c|c|c|}
\hline position & 1 & 2 & 3 & 4 & 5 \\
\hline & $\delta_{\mathrm{H}}, \mathrm{m}(J$ in $\mathrm{Hz})$ & $\delta_{\mathrm{H}}, \mathrm{m}(J$ in $\mathrm{Hz})$ & $\delta_{\mathrm{H}}, \mathrm{m}(J$ in $\mathrm{Hz})$ & $\delta_{\mathrm{H}}, \mathrm{m}(J$ in $\mathrm{Hz})$ & $\delta_{\mathrm{H}}, \mathrm{m}(J$ in $\mathrm{Hz})$ \\
\hline 1 & - & $5.01, \mathrm{~d}(4.0)$ & - & - & - \\
\hline $2 \mathrm{a}$ & $3.85, \mathrm{~d}(17.0)$ & $2.84^{b}$ & $3.81, \mathrm{~d}(17.0)$ & $3.86^{i}$ & $3.21, \mathrm{~d}(13.8)$ \\
\hline $2 \mathrm{~b}$ & $3.99, \mathrm{~d}(17.0)$ & $\begin{array}{l}4.13 \text {, dd (14.1, } \\
5.1)\end{array}$ & $4.00, \mathrm{~d}(17.0)$ & $3.88^{i}$ & $3.82, \mathrm{~d}(13.8)$ \\
\hline $3(\mathrm{~N}-\mathrm{H})$ & n.o. & n.o. & n.o. & $8.71, \mathrm{t}(5.4)$ & n.o. \\
\hline 5 & $4.53, \mathrm{~m}$ & $4.28, \mathrm{~m}$ & $\begin{array}{l}4.40, \mathrm{dd}(10.8, \\
4.5)\end{array}$ & $4.38^{j}$ & $4.35, \mathrm{~m}$ \\
\hline $6(\mathrm{~N}-\mathrm{H})$ & n.o. & n.o. & n.o. & 7.81, d (9.5) & n.o. \\
\hline 8 & $4.73, \mathrm{~s}$ & $4.71, \mathrm{~s}$ & $4.62, \mathrm{~s}$ & $4.43^{j}$ & $4.43, \mathrm{~d}(9.4)$ \\
\hline 9 & - & - & - & $4.80, \mathrm{~d}(8.5)$ & $\begin{array}{l}\text { 4.81, dd (9.4, } \\
2.0)\end{array}$ \\
\hline 12 & 7.24, d (8.9) & 7.14, d (8.4) & $\begin{array}{l}7.18, \mathrm{dd}(8.3, \\
2.2)\end{array}$ & $7.01^{k}$ & $\begin{array}{l}6.90, \mathrm{dd}(8.9, \\
2.7)\end{array}$ \\
\hline 13 & 7.34, d (8.9) & $7.32^{c}$ & $\begin{array}{l}7.39 \text {, dd (8.2, } \\
2.1)\end{array}$ & 7.39, d (8.5) & $\begin{array}{l}7.34, \mathrm{dd}(8.7, \\
2.2)\end{array}$ \\
\hline 15 & 7.34, d (8.9) & $6.95^{d}$ & $7.31^{f}$ & $\begin{array}{l}7.22 \text {, dd (8.5, } \\
2.0)\end{array}$ & $\begin{array}{l}7.21, \mathrm{dd}(8.6, \\
2.2)\end{array}$ \\
\hline 16 & $\begin{array}{l}7.14, \text { dd }(9.6, \\
2.1)\end{array}$ & $6.97^{d}$ & $\begin{array}{l}\text { 7.12, dd (8.4, } \\
2.3)\end{array}$ & $6.97^{k}$ & $\begin{array}{l}\text { 6.81, dd (8.6, } \\
2.5)\end{array}$ \\
\hline $17 \mathrm{a}$ & $\begin{array}{l}2.56, \text { dd (14.1, } \\
4.3)\end{array}$ & $\begin{array}{l}2.64, \text { dd }(14.3, \\
4.7)\end{array}$ & $\begin{array}{l}2.58, \text { dd (14.1, } \\
4.6)\end{array}$ & $2.38, \mathrm{~m}$ & $2.70, \mathrm{~d}(7.0)$ \\
\hline $17 b$ & $\begin{array}{l}2.96, \text { dd (14.0, } \\
11.3)\end{array}$ & $\begin{array}{l}2.97, \text { dd (14.3, } \\
10.4)\end{array}$ & $\begin{array}{l}2.98, \text { dd }(14.0 \\
10.9)\end{array}$ & $\begin{array}{l}2.78, \text { dd }(15.7 \\
9.2)\end{array}$ & $2.82, \mathrm{~d}(7.0)$ \\
\hline 20 & $7.40, \mathrm{~d}(8.2)$ & $7.44, d(8.0)$ & 7.44, d (7.9) & $8.39, \mathrm{~m}$ & $8.78, \mathrm{~d}(1.4)$ \\
\hline 21 & $\begin{array}{l}\text { 6.94, dd (8.0, } \\
7.6)\end{array}$ & $6.99^{d}$ & $\begin{array}{l}6.99, \text { ddd }(8.2 \\
7.5,1.0)\end{array}$ & $8.40^{1}$ & N-H, n.o. \\
\hline 22 & $\begin{array}{l}7.05, \text { dd }(8.2, \\
7.6)\end{array}$ & $\begin{array}{l}7.07, \mathrm{dd}(8.0, \\
7.5)\end{array}$ & $\begin{array}{l}7.07, \text { ddd }(8.0 \\
7.6,1.0)\end{array}$ & $6.99^{k}$ & $7.25, \mathrm{~s}$ \\
\hline
\end{tabular}




\begin{tabular}{|c|c|c|c|c|c|}
\hline 23 & $7.27, \mathrm{~d}(8.2)$ & $7.30^{c}$ & $7.30^{f}$ & $2.16, \mathrm{~m}$ & $2.24, \mathrm{~m}$ \\
\hline 24 & - & - & - & $1.09^{m}$ & $1.10, \mathrm{~d}(7.0)$ \\
\hline 25 & N-H, n.o. & N-H, n.o. & N-H, n.o. & $0.85, \mathrm{~d}(6.7)$ & $0.97, \mathrm{~d}(7.0)$ \\
\hline 26 & $6.89, \mathrm{~s}$ & $6.95^{d}$ & $6.91, \mathrm{~s}$ & $8.34, \mathrm{~d}(9.7)$ & N-H, n.o. \\
\hline 27 & $1.92, \mathrm{~s}$ & $1.91, \mathrm{~s}$ & $1.44, \mathrm{~s}$ & - & - \\
\hline 28 & $1.49, \mathrm{~s}$ & $1.46, \mathrm{~s}$ & $1.92, \mathrm{~s}$ & $4.27^{j}$ & $4.26, \mathrm{~d}(9.4)$ \\
\hline 29 & N-H, n.o. & N-H, n.o. & N-H, n.o. & $1.63, \mathrm{~m}$ & $1.80, \mathrm{~m}$ \\
\hline $30 a$ & - & - & - & $1.06^{m}$ & $1.24^{\mathrm{n}}$ \\
\hline $30 \mathrm{~b}$ & - & - & - & $1.33, \mathrm{~m}$ & $1.54, \mathrm{~m}$ \\
\hline 31 & $4.29, \mathrm{~d}(9.0)$ & $4.35, \mathrm{~d}(8.6)$ & $4.25, \mathrm{~d}(7.7)$ & $0.74, \mathrm{t}(7.4)$ & $0.91, \mathrm{t}(7.4)$ \\
\hline 32 & $1.97, \mathrm{~m}$ & $2.00, \mathrm{~m}$ & $1.96, \mathrm{~m}$ & $0.63, \mathrm{~d}(6.8)$ & $0.77, \mathrm{~d}(6.9)$ \\
\hline 33 & $0.86, \mathrm{~d}(6.7)$ & $0.91, \mathrm{~d}(6.7)$ & $0.92^{g}$ & $8.43^{1}$ & N-H, n.o. \\
\hline 34 & $0.93, \mathrm{~d}(6.7)$ & $0.96, \mathrm{~d}(6.7)$ & $0.91^{g}$ & - & - \\
\hline 35 & N-H, n.o. & N-H, n.o. & N-H, n.o. & $3.57^{p}$ & $3.87, \mathrm{~d}(4.9)$ \\
\hline 36 & - & - & - & $1.93, \mathrm{~m}$ & $2.16, \mathrm{~m}$ \\
\hline $37 \mathrm{a}$ & $3.60, \mathrm{~d}(6.6)$ & $3.75, \mathrm{~m}$ & $3.90, \mathrm{~m}$ & $1.11^{m}$ & $1.23^{n}$ \\
\hline $37 b$ & - & - & - & $1.60, \mathrm{~m}$ & $1.66, \mathrm{~m}$ \\
\hline 38 & $2.06, \mathrm{~m}$ & $2.13, \mathrm{~m}$ & $2.37, \mathrm{~m}$ & $0.89, \mathrm{t}(7.3)$ & $1.04^{\circ}$ \\
\hline $39 a$ & $1.20, \mathrm{~m}$ & $1.23, \mathrm{~m}$ & $1.46, \mathrm{~m}$ & $0.81, \mathrm{~d}(6.6)$ & $1.02^{\circ}$ \\
\hline $39 b$ & $1.65, \mathrm{~m}$ & $1.67, \mathrm{~m}$ & $1.71, \mathrm{~m}$ & - & - \\
\hline 40 & $1.02, \mathrm{t}(7.4)$ & $1.03^{e}$ & $1.04^{h}$ & - & - \\
\hline 41 & $0.97, \mathrm{~d}(6.6)$ & $1.00^{e}$ & $1.06^{h}$ & $2.59, \mathrm{~s}$ & $2.90, \mathrm{~s}$ \\
\hline 42 & - & - & - & $2.51, \mathrm{~m}$ & $2.94, \mathrm{~s}$ \\
\hline 43 & $2.69, \mathrm{~s}$ & $2.85, \mathrm{~s}^{\mathrm{b}}$ & $3.46, \mathrm{~s}$ & & \\
\hline 44 & $2.69, \mathrm{~s}$ & $2.85, \mathrm{~s}^{\mathrm{b}}$ & $3.32^{q}$ & & \\
\hline
\end{tabular}

${ }^{a}$ Spectra were recorded at $400 \mathrm{MHz}$. Solvent for compounds 1-3 and 5: methanol- $d_{4}$, compound 4: DMSO- $d_{6}$. n.o.: not observed. ${ }^{b-o}$ Overlapping signals. ${ }^{p}$ Overlapping with residual water signal. ${ }^{q}$ Overlapping with methanol signal. 
Table 2. ${ }^{13} \mathrm{C}$ NMR Spectroscopic Data $\left(\delta_{\mathrm{C}}\right.$ in ppm, type) for compounds $1-5^{a}$

\begin{tabular}{|c|c|c|c|c|c|}
\hline \multirow{2}{*}{ position } & 1 & 2 & 3 & 4 & 5 \\
\hline & $\delta_{\mathrm{C}}$, type & $\delta_{\mathrm{C}}$, type & $\delta_{\mathrm{C}}$, type & $\delta_{\mathrm{C}}$, type & $\delta_{\mathrm{C}}$, type \\
\hline 1 & 205.1, C & $73.4, \mathrm{CH}$ & 203.6, C & 203.2, C & 105.5, C \\
\hline 2 & $50.9, \mathrm{CH}_{2}$ & $48.8, \mathrm{CH}_{2}$ & $49.3, \mathrm{CH}_{2}$ & $50.2, \mathrm{CH}_{2}$ & $45.5, \mathrm{CH}_{2}$ \\
\hline 4 & 174.0, C & 173.3, C & $172.3, \mathrm{C}$ & $170.3, \mathrm{C}$ & $170.8, \mathrm{C}$ \\
\hline 5 & $54.5, \mathrm{CH}$ & $55.6, \mathrm{CH}$ & $52.9, \mathrm{CH}$ & $50.9, \mathrm{CH}$ & $52.7, \mathrm{CH}$ \\
\hline 7 & $170.3, \mathrm{C}$ & $170.5, \mathrm{C}$ & $168.8, \mathrm{C}$ & $170.2, \mathrm{C}$ & $172.3, \mathrm{C}$ \\
\hline 8 & $59.2, \mathrm{CH}$ & $60.6, \mathrm{CH}$ & $57.6, \mathrm{CH}$ & $54.9, \mathrm{CH}$ & $56.6, \mathrm{CH}$ \\
\hline 9 & $85.5, \mathrm{C}$ & $85.4, \mathrm{C}$ & $83.8, \mathrm{C}$ & $81.8, \mathrm{CH}$ & $79.6, \mathrm{CH}$ \\
\hline 11 & $159.3, \mathrm{C}$ & $156.9, \mathrm{C}$ & 157.7, C & 158.6, C & $158.8, \mathrm{C}$ \\
\hline 12 & $125.5, \mathrm{CH}$ & $124.0, \mathrm{CH}$ & $123.9, \mathrm{CH}$ & 117.2, $\mathrm{CH}$ & $113.4, \mathrm{CH}$ \\
\hline 13 & $130.6, \mathrm{CH}$ & $128.1, \mathrm{CH}$ & $129.0, \mathrm{CH}$ & $129.5, \mathrm{CH}$ & $130.8, \mathrm{CH}$ \\
\hline 14 & 134.2, C & 139.2, C & 132.6, C & $130.6, \mathrm{C}$ & $132.5, \mathrm{C}$ \\
\hline 15 & $130.2, \mathrm{CH}$ & $128.9, \mathrm{CH}$ & $128.5, \mathrm{CH}$ & 129.1, CH & $129.9, \mathrm{CH}$ \\
\hline 16 & $123.4, \mathrm{CH}$ & $125.2, \mathrm{CH}$ & $121.8, \mathrm{CH}$ & 121.2, $\mathrm{CH}$ & $119.9, \mathrm{CH}$ \\
\hline 17 & $29.4, \mathrm{CH}_{2}$ & $30.3, \mathrm{CH}_{2}$ & $27.8, \mathrm{CH}_{2}$ & 28.3, $\mathrm{CH}_{2}$ & $29.5, \mathrm{CH}_{2}$ \\
\hline 18 & $110.6, \mathrm{C}$ & $111.4, \mathrm{C}$ & 109.0, C & $163.4, \mathrm{C}$ & $130.4, \mathrm{C}$ \\
\hline 19 & 128.6, C & $129.3, \mathrm{C}$ & 127.0, C & - & - \\
\hline 20 & $119.2, \mathrm{CH}$ & $119.9, \mathrm{CH}$ & 117.6, CH & $134.3, \mathrm{CH}$ & $135.0, \mathrm{CH}$ \\
\hline 21 & $119.9, \mathrm{CH}$ & $120.4, \mathrm{CH}$ & $118.3, \mathrm{CH}$ & - & - \\
\hline 22 & 122.7, CH & $123.2, \mathrm{CH}$ & $121.0, \mathrm{CH}$ & $116.5, \mathrm{CH}$ & $118.6, \mathrm{CH}$ \\
\hline 23 & $112.5, \mathrm{CH}$ & $113.0, \mathrm{CH}$ & $110.9, \mathrm{CH}$ & $28.2, \mathrm{CH}$ & $29.9, \mathrm{CH}$ \\
\hline 24 & 138.2, C & 138.7, C & 136.6, C & $20.8, \mathrm{CH}_{3}$ & 20.6, $\mathrm{CH}_{3}$ \\
\hline 25 & - & - & - & $15.1, \mathrm{CH}_{3}$ & $15.4, \mathrm{CH}_{3}$ \\
\hline 26 & 124.1, CH & 124.7, CH & 122.6, CH & - & - \\
\hline
\end{tabular}




\begin{tabular}{|c|c|c|c|c|c|}
\hline 27 & $25.0, \mathrm{CH}_{3}$ & $25.4, \mathrm{CH}_{3}$ & $29.1, \mathrm{CH}_{3}$ & $169.8, \mathrm{C}$ & $172.2, \mathrm{C}$ \\
\hline 28 & $30.8, \mathrm{CH}_{3}$ & $31.1, \mathrm{CH}_{3}$ & 23.3, $\mathrm{CH}_{3}$ & $56.8, \mathrm{CH}$ & $59.2, \mathrm{CH}$ \\
\hline 29 & - & - & - & $36.8, \mathrm{CH}$ & $37.8, \mathrm{CH}$ \\
\hline 30 & $173.0 \mathrm{C}$ & 173.6, C & $171.5, \mathrm{C}$ & $24.9, \mathrm{CH}_{2}$ & $26.5, \mathrm{CH}_{2}$ \\
\hline 31 & $60.5, \mathrm{CH}$ & $61.2, \mathrm{CH}$ & $58.7, \mathrm{CH}$ & $10.8, \mathrm{CH}_{3}$ & $10.9, \mathrm{CH}_{3}$ \\
\hline 32 & $32.5, \mathrm{CH}$ & $33.1, \mathrm{CH}$ & $30.7, \mathrm{CH}$ & $15.3, \mathrm{CH}_{3}$ & $15.9, \mathrm{CH}_{3}$ \\
\hline 33 & $20.0, \mathrm{CH}_{3}$ & $20.4, \mathrm{CH}_{3}$ & $18.4, \mathrm{CH}_{3}$ & - & - \\
\hline 34 & $19.8, \mathrm{CH}_{3}$ & $20.2, \mathrm{CH}_{3}$ & $17.7, \mathrm{CH}_{3}$ & $169.9, \mathrm{C}$ & 167.0, C \\
\hline 35 & - & - & - & $70.9, \mathrm{CH}$ & 73.7, $\mathrm{CH}$ \\
\hline 36 & $169.7, \mathrm{C}$ & $168.4, \mathrm{C}$ & $166.6, \mathrm{C}$ & $33.2, \mathrm{CH}$ & $35.4, \mathrm{CH}$ \\
\hline 37 & $73.9, \mathrm{CH}$ & $74.2, \mathrm{CH}$ & $82.4, \mathrm{CH}$ & $25.6, \mathrm{CH}_{2}$ & 27.6, $\mathrm{CH}_{2}$ \\
\hline 38 & $35.3, \mathrm{CH}$ & $35.9, \mathrm{CH}$ & $33.0, \mathrm{CH}$ & $11.5, \mathrm{CH}_{3}$ & $12.3, \mathrm{CH}_{3}$ \\
\hline 39 & 27.2, $\mathrm{CH}_{2}$ & $28.0, \mathrm{CH}_{2}$ & $28.9, \mathrm{CH}_{2}$ & $14.1, \mathrm{CH}_{3}$ & $13.2, \mathrm{CH}_{3}$ \\
\hline 40 & $12.0, \mathrm{CH}_{3}$ & $12.7, \mathrm{CH}_{3}$ & $10.5, \mathrm{CH}_{3}$ & - & - \\
\hline 41 & $14.3, \mathrm{CH}_{3}$ & $14.3, \mathrm{CH}_{3}$ & $15.7, \mathrm{CH}_{3}$ & $40.2, \mathrm{CH}_{3}$ & $43.9, \mathrm{CH}_{3}$ \\
\hline 42 & - & - & - & 41.6, $\mathrm{CH}_{3}$ & $41.6, \mathrm{CH}_{3}$ \\
\hline 43 & $42.7, \mathrm{CH}_{3}$ & $43.2, \mathrm{CH}_{3}$ & $55.3, \mathrm{CH}_{3}$ & & \\
\hline 44 & $42.7, \mathrm{CH}_{3}$ & $43.2, \mathrm{CH}_{3}$ & $56.9, \mathrm{CH}_{3}$ & & \\
\hline
\end{tabular}

${ }^{a}$ Spectra were recorded at $100 \mathrm{MHz}$. Solvent for compounds 1-3 and 5: methanol- $\mathrm{d}_{4}$, compound 4: $\mathrm{DMSO}_{\mathrm{d}}$.

The antiplasmodial activity against Plasmodium falciparum strain K1 and cytotoxicity for MRC-5 cells (human fetal lung fibroblast cells) were determined for compounds $\mathbf{1 - 4}$ and the results are displayed in Table 3 . All four compounds showed antiplasmodial activity with $\mathrm{IC}_{50}$ values ranging between 12.2 and $27.9 \mu \mathrm{M}$. Compound $\mathbf{1}$ was the only compound that showed cytotoxicity with an $\mathrm{IC}_{50}$ of $51.1 \pm 17.2 \mu \mathrm{M}$, for the other compounds no cytotoxicity was observed in a concentration up to $64.0 \mu \mathrm{M}\left(\mathrm{IC}_{50}>64.0 \mu \mathrm{M}\right)$. 
Table 3. Antiplasmodial activity against $P$. falciparum strain $\mathrm{K} 1$ and Cytotoxicity against MRC5-cells $\left(\mathrm{IC}_{50} \mu \mathrm{M}\right)$ for compounds 1 (hymenocardine), 2 (hymenocardinol), 3 (hymenocardine $\mathrm{N}$-oxide) and 4 (hymenocardine-H), Obtained from Root Bark of Hymenocardia acida.

\begin{tabular}{c|cc} 
compound & P. falciparum K1 & MRC-5 \\
$\mathbf{1}$ & $16.4 \pm 6.8$ & $51.1 \pm 17.2$ \\
$\mathbf{2}$ & $17.5 \pm 8.7$ & $>64.0$ \\
$\mathbf{3}$ & $12.2 \pm 6.6$ & $>64.0$ \\
$\mathbf{4}$ & $27.9 \pm 16.5$ & $>64.0$ \\
chloroquine & $0.2 \pm 0.1$ & -
\end{tabular}

From previous results by Suksamrarn et al. and Panseeta et al. it appeared that all cyclopeptide alkaloids with antiplasmodial activity contained a $\beta$-hydroxy proline unit, although this amino acid was also present in inactive compounds. Moreover the importance of the methoxy group in the styrylamine moiety and the methylation of the terminal nitrogen atom were suggested. ${ }^{8,9}$ Compounds 1-4 do not contain a $\beta$-hydroxy proline moiety nor a methoxy group, but they do have methylated terminal nitrogens. It can be concluded that the presence of the $\beta$-hydroxy proline and the methoxy group might be an indication for antiplasmodial activity, but that those functional groups are not indispensable and cyclopeptide alkaloids with other functional groups can also show antiplasmodial activity. It can be hypothesized that the terminal N-methyl groups are crucial for the antiplasmodial activity. In view of the moderate antiplasmodial activity of the isolated constituents, it is not clear to what extent these cyclopeptides could explain the traditional use against malaria. 


\section{EXPERIMENTAL SECTION}

General Experimental Procedures. Optical rotations were determined on a Jasco P-2000 spectropolarimeter (Easton, MD, USA) with Spectramanager software and with methanol as blank. NMR spectra were recorded on a Bruker DRX-400 NMR spectrometer (Rheinstetten, Germany) operating at $400 \mathrm{MHz}$ for ${ }^{1} \mathrm{H}$ and at $100 \mathrm{MHz}$ for ${ }^{13} \mathrm{C}$ NMR spectra. The spectra were processed with Topspin version 1.3. An Agilent QTOF 6530 mass spectrometer (Santa Clara, CA, USA) with MassHunter version B.06 software was used to perform accurate mass measurements. The mass spectrometer was operated in the ESI+ mode at a resolution of 20,000. Calibration was done externally and the samples were measured after direct infusion.

A semi-preparative HPLC system with DAD and ESIMS detectors was used for isolation of the pure compounds and was comprised of a sample manager, injector and collector (2767), a quaternary gradient module (2545), a System Fluidics Organizer, an HPLC-pump (515), a photodiode array detector (2998) and a Micromass Quattro mass spectrometer with TQD, all supplied by Waters (Milford, MA, USA). MassLynx version 4.1 was used to process the data. A Grace Reveleris X2 flash chromatography system (Lokeren, Belgium) was used for fractionation of the plant material. TLC was performed on $\mathrm{NP} \mathrm{F}_{254}$ plates $(20 \mathrm{~cm} \times 20 \mathrm{~cm})$ from Merck (Darmstadt, Germany) and the spots were observed under UV light (254 and $366 \mathrm{~nm}$ ) and under visible light after spraying with Dragendorff reagent and iodoplatinate reagent.

Dichloromethane, chloroform, methanol and acetonitrile were of HPLC-quality and hydrochloric acid (37\%) and ammonia (25\%) were purchased from Fisher Chemical (Loughborough, UK). Formic acid, glacial acetic acid, potassium iodide, and hydrogen hexachloroplatinate (IV) hydrate were supplied by Acros Organics (Geel, Belgium). Methanol- $d_{4}$ $\left(99.8 \%\right.$ D) and DMSO- $d_{6}(99.9 \%$ D) were from Sigma-Aldrich (Steinheim, Germany). Bismuth 
subnitrate was bought from Merck KGaA (Darmstadt, Germany). Milli-Q water was prepared with a Millipore water purification system (Bedford, MA, USA).

Plant Material. The root bark of Hymenocardia acida was collected in December 2012 in Dubréka, Guinea-Conakry. A specimen of this plant is maintained at the Research and Valorization Center on Medicinal Plants in Dubréka (voucher code 62HK530).

Extraction and Isolation. A crude extract was prepared from $2.7 \mathrm{~kg}$ of the dried and milled root bark of $H$. acida by means of percolation with $80 \% \mathrm{CH}_{3} \mathrm{OH} / 20 \% \mathrm{H}_{2} \mathrm{O}$ (83 L in total). After evaporation of the solvent and freeze-drying, $356.9 \mathrm{~g}$ of crude extract remained. The crude extract was re-dissolved in $50 \% \mathrm{CH}_{3} \mathrm{OH} / 50 \% \mathrm{H}_{2} \mathrm{O}$ and acidified to $\mathrm{pH}<3$ with $\mathrm{HCl} 2 \mathrm{M}$. Then, a liquid-liquid partition was performed with $\mathrm{CHCl}_{3}$. After this, the $\mathrm{pH}$ of the $\mathrm{CH}_{3} \mathrm{OH} / \mathrm{H}_{2} \mathrm{O} / \mathrm{H}^{+}$ phase was increased to $>9$ by addition of $\mathrm{NH}_{4} \mathrm{OH}(25 \%)$, followed by a second liquid-liquid partition with $\mathrm{CHCl}_{3}$. Thus, the plant material was divided into three fractions: $\mathrm{CHCl}_{3}(\mathrm{I}), \mathrm{CHCl}_{3}$ (II), and $\mathrm{CH}_{3} \mathrm{OH} / \mathrm{H}_{2} \mathrm{O}(\mathrm{pH}>9)$. TLC analysis of these three fractions was performed with $\mathrm{CHCl}_{3}-\mathrm{CH}_{3} \mathrm{OH}-\mathrm{NH}_{3}(60: 30: 10)$ as the mobile phase and the plates were observed under UV light (254 and $366 \mathrm{~nm}$ ) and under visible light after spraying with Dragendorff and iodoplatinate reagents.

The TLC analysis indicated that alkaloids were only present in the $\mathrm{CHCl}_{3}$ (II) phase $(8.27 \mathrm{~g})$. Further fractionation of this phase was performed by flash chromatography on a GraceResolv $120 \mathrm{~g}$ silica column. The solvents $\mathrm{CH}_{2} \mathrm{Cl}_{2}$ (A), EtOAc (B) and $\mathrm{CH}_{3} \mathrm{OH}(\mathrm{C})$ were used as follows: 0 min $100 \% \mathrm{~A}, 0 \% \mathrm{~B}, 0 \% \mathrm{C}$, changing linearly to $0 \% \mathrm{~A}$ and $100 \% \mathrm{~B}$ at $40 \mathrm{~min}$; then a linear change to $50 \% \mathrm{~B} / 50 \% \mathrm{C}$ in a 20 min time span, which was retained between 60 and 80 min; from 80 to 100 min a linear change to $100 \%$ C; finally, this condition was maintained until 115 
min. The flow rate was $13 \mathrm{~mL} / \mathrm{min}$ and for detection ELSD and UV-absorption at $254 \mathrm{~nm}$ and $366 \mathrm{~nm}$ were used. Throughout the whole experiment the eluent was collected in test tubes, based on the ELSD and UV-absorption intensity. Together with TLC analysis, which was performed as described above, test tubes which showed a similar pattern were combined. This resulted in 12 fractions.

Fractions 11 and 12 were selected based on their TLC profiles $\left(\mathrm{CH}_{2} \mathrm{Cl}_{2}-\mathrm{CH}_{3} \mathrm{OH}-\mathrm{NH}_{3}\right.$ 95:5:2) and were submitted to semi-preparative HPLC. The system was operated with a $\mathrm{C}_{18}$ Luna column (250 mm x $10.0 \mathrm{~mm}$, particle size, $5 \mu \mathrm{m}$ ) from Phenomenex (Utrecht, The Netherlands) and a $\mathrm{C}_{18}$ guard column $(10 \mathrm{~mm} \times 10 \mathrm{~mm}$, particle size, $5 \mu \mathrm{m})$ from Grace (Hesperia, CA, USA). Linear gradients with $\mathrm{H}_{2} \mathrm{O}+0.1 \%$ formic acid (A) and acetonitrile (B) were applied. For fraction 11: 0 to 5 min. $20 \%$ B, $25 \min .30 \%$ B, $40-45 \min$. $100 \%$ B. For fraction 12: 0 to 5 min. $20 \%$ B, 20 min. $25 \%$ B, 35 min. $45 \%$ B, 40-45 min. $100 \%$ B. The flow rate was $3.0 \mathrm{~mL} / \mathrm{min}$. Sample concentration $25 \mathrm{mg} / \mathrm{mL}$; injection volume fraction 11: $400 \mu \mathrm{L}$, fraction 12: $200 \mu \mathrm{L}$. The DAD spectrum was recorded from $200 \mathrm{~nm}$ to $450 \mathrm{~nm}$ and mass spectra were taken in ESI+ mode, MS scan range: $m / z, 150$ to $750 . \mathrm{V}_{\text {capillary }} 3.00 \mathrm{kV}, \mathrm{V}_{\text {cone }} 50 \mathrm{~V}, \mathrm{~V}_{\text {extractor }} 3 \mathrm{~V}, \mathrm{~V}_{\mathrm{RF} \text { Lens }} 0.2 \mathrm{~V}, \mathrm{~T}_{\text {source }} 135$ ${ }^{\circ} \mathrm{C}, \mathrm{T}_{\text {Desolvation }} 400{ }^{\circ} \mathrm{C}$, desolvation gas flow $750 \mathrm{~L} / \mathrm{h}$, cone gas flow $50 \mathrm{~L} / \mathrm{h}$. Collection triggers for fraction 11: $\mathrm{m} / \mathrm{z} \mathrm{m} / \mathrm{z}, 659$ or 675 with a treshold of $1.1 \times 10^{6}$ resulted in hymenocardine (1) and hymenocardinol (2). For fraction 12, the automatic collection was triggered by $\mathrm{m} / \mathrm{z} 654 ; \mathrm{m} / z 675$ or $m / z, 691$ reaching a treshold of $1.5 \times 10^{6}$. Again hymenocardine (1) was isolated, together with hymenocardine $\mathrm{N}$-oxide (3) and hymenocardine-H (4).

Hymenocardine (1): (561 mg) yellowish powder; $[\alpha]_{\mathrm{D}}=-106.8\left(c 0.5, \mathrm{CH}_{3} \mathrm{OH}\right) ; \mathrm{UV} \lambda_{\max } 201$, $263 \mathrm{~nm} ;{ }^{1} \mathrm{H}$ NMR (methanol- $d_{4}, 400 \mathrm{MHz}$ ) and ${ }^{13} \mathrm{C}$ NMR (methanol- $d_{4}, 100 \mathrm{MHz}$ ), see Tables 1 
and 2, respectively, HRESIMS $m / z 675.3893[\mathrm{M}+\mathrm{H}]^{+} ; 697.3705[\mathrm{M}+\mathrm{Na}]^{+}$and $713.3444[\mathrm{M}+\mathrm{K}]^{+}$ (calcd. for $\mathrm{C}_{37} \mathrm{H}_{51} \mathrm{~N}_{6} \mathrm{O}_{6}, 675.3865$ )

Hymenocardinol (2): (39 mg) yellowish powder; $[\alpha]_{\mathrm{D}}-75.6\left(c 0.5, \mathrm{CH}_{3} \mathrm{OH}\right)$; UV $\lambda_{\max } 201$, 221, $278 \mathrm{~nm} ;{ }^{1} \mathrm{H}$ NMR (methanol- $d_{4}, 400 \mathrm{MHz}$ ) and ${ }^{13} \mathrm{C} \mathrm{NMR}$ (methanol- $d_{4}, 100 \mathrm{MHz}$ ), see Tables 1 and 2, respectively, HRESIMS $m / z \quad 677.4079[\mathrm{M}+\mathrm{H}]^{+} ; 699.3898[\mathrm{M}+\mathrm{Na}]^{+}$and $715.3641[\mathrm{M}+\mathrm{K}]^{+}$(calcd. for $\mathrm{C}_{37} \mathrm{H}_{53} \mathrm{~N}_{6} \mathrm{O}_{6}, 677.4027$ )

Hymenocardine $N$-oxide (3): $(5 \mathrm{mg})$ yellowish powder; $[\alpha]_{\mathrm{D}}-100.7\left(c 0.4, \mathrm{CH}_{3} \mathrm{OH}\right) ; \mathrm{UV} \lambda_{\max }$ 204, 220, $263 \mathrm{~nm} ;{ }^{1} \mathrm{H}$ NMR (methanol- $d_{4}, 400 \mathrm{MHz}$ ) and ${ }^{13} \mathrm{C}$ NMR (methanol- $d_{4}, 100 \mathrm{MHz}$ ), see Tables 1 and 2, respectively, HRESIMS $m / z 691.3855[\mathrm{M}+\mathrm{H}]^{+}$and $713.3605[\mathrm{M}+\mathrm{Na}]^{+}$(calcd for $^{2}$ $\left.\mathrm{C}_{37} \mathrm{H}_{52} \mathrm{~N}_{6} \mathrm{O}_{7}, 691.3814\right)$.

Hymenocardine-H (4): white powder; $[\alpha]_{\mathrm{D}}-55.5\left(c 0.9 \mathrm{CH}_{3} \mathrm{OH}\right) ; \mathrm{UV} \lambda_{\max } 206,266 \mathrm{~nm} ;{ }^{1} \mathrm{H}$ NMR (DMSO- $d_{6}, 400 \mathrm{MHz}$ ) and ${ }^{13} \mathrm{C}$ NMR (DMSO- $d_{6}, 100 \mathrm{MHz}$ ), see Tables 1 and 2, respectively. HRESIMS $m / z 654.4018[\mathrm{M}+\mathrm{H}]^{+} ; 676.3837[\mathrm{M}+\mathrm{Na}]^{+}$and $692.3620[\mathrm{M}+\mathrm{K}]^{+}(\mathrm{calcd}$ for $\left.\mathrm{C}_{34} \mathrm{H}_{51} \mathrm{~N}_{7} \mathrm{O}_{6}, 654.3974\right)$.

Antiplasmodial and Cytotoxicity Ativities. The antiplasmodial and cytotoxicity activity determinations of the isolated components were performed as reported before. ${ }^{16,17}$ The antiplasmodial activity of the isolated compounds was tested against the chloroquine-resistant strain Plasmodium falciparum K1. The parasite was maintained in continuous log phase growth in RPMI-1640 medium supplemented with 2\% P/S solution, $0.37 \mathrm{mM}$ hypoxanthine, $25 \mathrm{mM}$ HEPES, $25 \mathrm{mM} \mathrm{NaHCO}_{3}$ and 10\% O+ human serum together with 4\% human $\mathrm{O}+$ erythrocytes. All cultures and assays were conducted at $37{ }^{\circ} \mathrm{C}$ under micro-aerophilic atmosphere $\left(4 \% \mathrm{CO}_{2}\right.$, $3 \% \mathrm{O}_{2}$ and $93 \% \mathrm{~N}_{2}$ ). The in vitro antimalarial activity was assessed using the lactate 
dehydrogenase assay. Stock solutions of test compounds were prepared in DMSO at a concentration of $20 \mathrm{mM}$ and diluted with culture medium before being added to asynchronous parasite cultures. Assays were performed in 96-well tissue culture plates, each well containing 10 $\mu \mathrm{L}$ of the test solution containing the test compound together with $190 \mu \mathrm{L}$ of the parasite inoculum ( $1 \%$ parasitaemia, $2 \%$ haematocrit). After $72 \mathrm{~h}$ of incubation at $37{ }^{\circ} \mathrm{C}$, plates were stored at $-20{ }^{\circ} \mathrm{C}$ until further processing. After thawing, $20 \mu \mathrm{L}$ of haemolysed parasite suspension from each well was transferred into another plate together with $100 \mu \mathrm{L}_{\text {Malstat }}{ }^{\mathrm{TM}}$ reagent and $10 \mu \mathrm{L}$ of a $1 / 1$ mixture of PES (phenazine ethosulfate, $2 \mathrm{mg} / \mathrm{mL}$ ) and NBT (nitro blue tetrazolium grade III, $0.1 \mathrm{mg} / \mathrm{mL}$ ). The plates were kept in the dark for $2 \mathrm{~h}$ and change in colour was measured spectrophotometrically at $655 \mathrm{~nm}$. The results were expressed as percentage reduction in parasitaemia compared to control wells. The $\mathrm{IC}_{50}$ was calculated from the drug concentration-response curves. Chloroquine diphosphate was used as an antiplasmodial reference drug. The cytotoxicity was determined on MRC-5 cells (human lung fibroblast), which were cultured in MEM medium, supplemented with $20 \mathrm{mM} \mathrm{L}$-glutamine, $16.5 \mathrm{mM} \mathrm{NaHCO} 3,5 \%$ foetal calf serum and $2 \% \mathrm{P} / \mathrm{S}$ solution. Cultures were kept at $37{ }^{\circ} \mathrm{C}$ and $5 \% \mathrm{CO}_{2}$. Assays were performed in sterile 96-well tissue culture plates, each well containing $10 \mu \mathrm{L}$ of test solution containing the test compound, together with $190 \mu \mathrm{L}$ of cell suspension $\left(2.5 \times 10^{4}\right.$ cells $\left./ \mathrm{mL}\right)$. After 7 days incubation, cell proliferation/viability was assessed after addition of MTT (50 $\mu \mathrm{L}$ of a $1 / 2.5$ solution per well). After $4 \mathrm{~h}$ of incubation at $37^{\circ} \mathrm{C}$, the $\%$ absorbance reduction at $540 \mathrm{~nm}$ for the treated cultures and untreated control cultures were obtained and compared, and $\mathrm{IC}_{50}$ values were determined. The means and standard deviations of six and four experiments were calculated for compounds $\mathbf{1}, \mathbf{2}$ and 3,4 respectively. 


\section{ASSOCIATED CONTENT}

\section{Supporting Information}

The Supporting Information is available free of charge on the ACS Publications website at DOI:

${ }^{1} \mathrm{H}$ - and ${ }^{13} \mathrm{C}-\mathrm{NMR}$ spectra of compounds 1-3 and 5; ${ }^{1} \mathrm{H}-\mathrm{NMR}, \mathrm{COSY}, \mathrm{HSQC}$ and HMBC spectra for compound 4 (PDF)

\section{AUTHOR INFORMATION}

\section{Corresponding Author}

* Tel: +3232652731. Fax: +3232652709. E-mail: Emmy.Tuenter@uantwerpen.be.

\section{Notes}

The authors declare no competing financial interest.

\section{ACKNOWLEDGMENTS}

This work was supported by the Agency for Innovation by Science and Technology in Flanders (IWT). 


\section{REFERENCES}

(1) Wurdack, K. J.; Hoffmann, P.; Samuel, R.; De Bruijn, A.; Van der Bank, M.; Chase, M. W. Am. J. Bot. 2004, 91, 1882-1900.

(2) Starks, C. M.; Williams, R. B.; Norman, V. L.; Rice, S. M.; O'Neil-Johnson, M.; Lawrence, J. A.; Eldridge, G. R. Phytochemistry 2014, 98, 216-222.

(3) Pais, M.; Marchand, J.; Ratle, G.; Jarreau, F. X. B. Soc. Chim. Fr. 1968, 7, 2979-2984.

(4) Vonthron-Senecheau, C.; Weniger, B.; Ouattara, M.; Bi, F. T., Kamenan, A.; Lobstein, A.; Brun, R.; Anton, R. J. Ethnopharmacol. 2003, 87, 221-225.

(5) Manga, F. N.; El Khattabi, C.; Fontaine, J.; Berkenboom, G.; Duez, P.; Noyon, C.; Van Antwerpen, P.; Nzunzu, J. L.; Pochet, S. J. Ethnopharmacol. 2013, 146, 623-631.

(6) Mahmout, Y.; Mianpeurem, T.; Dolmazon, R.; Bouchu, D.; Fenet, B. Phytochemistry 2005, 7, 61-66.

(7) Obidike, I. C.; Aboh, M. I.; Salawu, O. A. J. Diet. Suppl. 2011, 8, 1-11.

(8) Suksamrarn, S.; Suwannapoch, N.; Aunchai, N.; Kuno, M.; Ratananukul, P.; Haritakun, R.; Jansakul, C.; Ruchirawat, S. Tetrahedron 2005, 61, 1175-1180.

(9) Panseeta, P.; Lomchoey, K.; Prabpai, S.; Kongsaeree, P.; Suksamrarn, A.; Ruchirawat, S.; Suksamrarn, S. Phytochemistry 2011, 72, 909-915.

(10) El-Seedi, H. R.; Zahra, M. H.; Goransson, U.; Verpoorte, R. Phytochem. Rev. 2007, 6, 143-165.

(11) Gournelis, D. C.; Laskaris, G. G.; Verpoorte, R. J. Nat. Prod. 1997, 26, 299-306.

(12) Pais, M.; Jarreau, F.-X.; Gonzalez Sierra, M.; Mascaretti, O. A.; Ruveda, E. A.; Chang, C. J.; Hagaman, E. W.; Wenkert, E. Phytochemistry 1979, 18, 1869-1872. 
(13) Han, J.; Ji, C. J.; He, W. J.; Shen, Y.; Leng, Y.; Xu, W. Y.; Fan, J. T.; Zeng, G. Z.; Kong, L. D.; Tan, N. H. J. Nat. Prod. 2011, 74, 2571-2575.

(14) Abu-Zarga, M.; Sabri, M.; Al-Aboudi, A. J. Nat. Prod. 1995, 58, 504-511.

(15) Ye, C. H.; Fu, R. Q.; Hu, J. Z.; Hou, L.; Ding, S. W. Magn. Reson. Chem. 1993, 31, 699704.

(16) Cos, P.; Vlietinck, A. J.; Vanden Berghe, D.; Maes, L. J. Ethnopharmacol. 2006, 106, 290-302.

(17) Mesia, G. K.; Tona, G. L.; Nanga, T. H.; Cimanga, R. K.; Apers, S.; Cos, P.; Maes, L.; Pieters, L.; Vlietinck, A. J. J. Ethnopharmacol. 2008, 115, 409-415. 


\section{TABLE OF CONTENTS /ABSTRACT GRAPHIC}
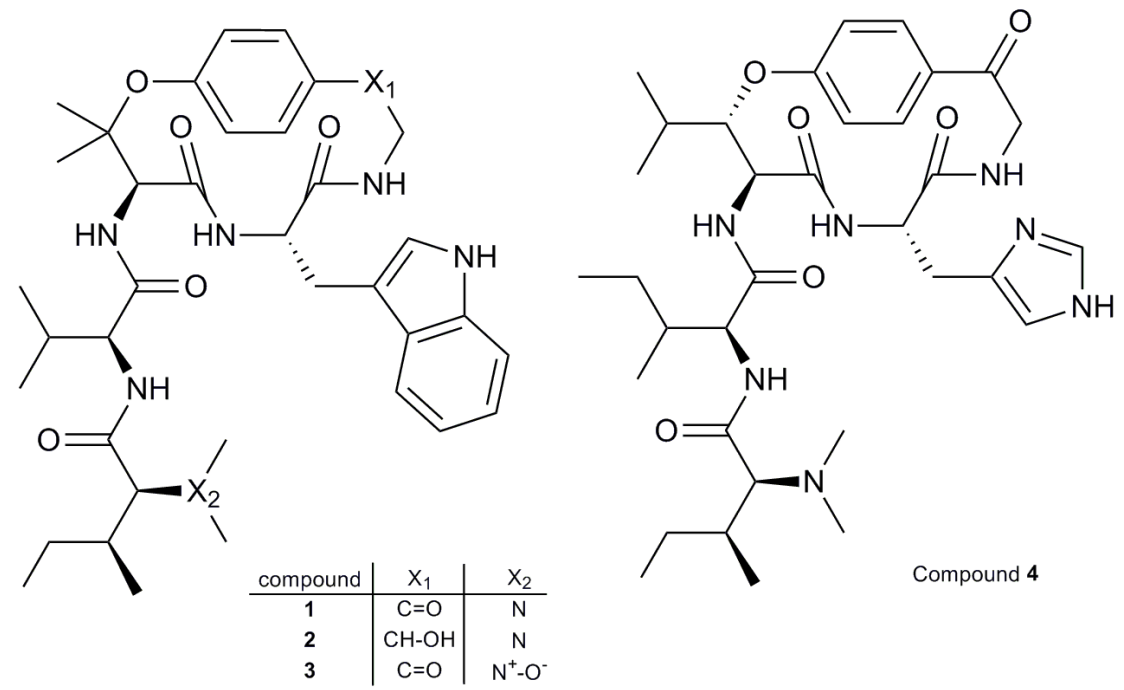